\title{
Azospirillum rugosum sp. nov., isolated from oil-contaminated soil
}

Correspondence
A. F. Yassin
yassin@mibi03.meb.uni-bonn.de

\author{
C. C. Young, ${ }^{1}$ H. Hupfer, ${ }^{2}$ C. Siering, ${ }^{2}$ M.-J. Ho, ${ }^{1}$ A. B. Arun, ${ }^{1}$ W.-A. Lai, ${ }^{1}$ \\ P. D. Rekha, ${ }^{1}$ F.-T. Shen, ${ }^{1}$ M.-H. Hung, ${ }^{1}$ W.-M. ${ }^{-}$Chen ${ }^{3}$ and A. F. Yassin ${ }^{4}$
}
${ }^{1}$ College of Agriculture and Natural Resources, Department of Soil and Environmental Sciences, National Chung Hsing University, Taichung 402, Taiwan, ROC
${ }^{2}$ Kekulé-Institut für Organische Chemie und Biochemie der Universität Bonn, 53121 Bonn, Germany
${ }^{3}$ Laboratory of Microbiology, Department of Seafood Science, National Kaohsiung Institute of Marine Technology, Nan-Tzu, Kaohsiung 811, Taiwan, ROC
${ }^{4}$ Institut für Medizinische Mikrobiologie und Immunologie der Universität Bonn, 53127 Bonn, Germany

\begin{abstract}
The taxonomic status of a light-orange-coloured bacterial isolate from an oil-contaminated soil sample was characterized by using a polyphasic taxonomic approach. Comparative analysis of 16S rRNA gene sequences demonstrated that the isolate belonged phylogenetically to the genus Azospirillum, with Azospirillum canadense, Azospirillum brasilense and Azospirillum doebereinerae as its closest phylogenetic relatives (97.3, 97.0 and $97.0 \%$ similarity, respectively). DNA-DNA pairing studies showed that the unidentified organism displayed 25.0, 17.0 and $19.0 \%$ relatedness to the type strains of $A$. brasilense, $A$. canadense and $A$. doebereinerae, respectively. The generic assignment was confirmed by chemotaxonomic data, which revealed a fatty acid profile that was characteristic of the genus Azospirillum, consisting of straight-chain saturated and unsaturated fatty acids with $\mathrm{C}_{18: 1} \omega 7 c$ as the major fatty acid, and ubiquinone with ten isoprene units $(\mathrm{Q}-10)$ as the predominant respiratory quinone. On the basis of both the phenotypic and molecular genetic evidence, it is proposed that the unknown isolate be classified as a representative of a novel species of the genus Azospirillum, for which the name Azospirillum rugosum sp. nov. is proposed. The type strain is IMMIB AFH-6 ${ }^{\top}$ (=CCUG $53966^{\top}=$ DSM $19657^{\top}$ ).
\end{abstract}

The genus Azospirillum was proposed by Tarrand et al. (1978) for strains of the root-associated nitrogen fixer 'Spirillum lipoferum', which appear as vibrioid cells with a single polar flagellum and have a DNA G $+C$ content of 69-71 mol\%. Recently, 16S rRNA gene sequence analysis has revealed that members of the genus Azospirillum form a distinct phylogenetic line within the Alphaproteobacteria. Furthermore, analysis of the quinone system and cellular fatty acids revealed that Azospirillum species contain ubiquinone Q-10 as the major respiratory quinone and that the fatty acid profile contains straight-chain saturated and unsaturated fatty acids in addition to 3-hydroxy fatty acids. Members of the genus Azospirillum have been isolated from the roots of numerous wild and cultivated grasses, cereals, food crops, and soil from tropical, subtropical and temperate regions all over the world (Döbereiner et al., 1976; Bally et al., 1983; Ladha et al.,

The GenBank/EMBL/DDBJ accession number for the $16 \mathrm{~S}$ rRNA gene sequence of strain IMMIB AFH-6 ${ }^{\top}$ is AM419042.
1987; Kirchhof et al., 1997; Gunarto et al., 1999). Members of the genus have been reported to enhance the growth of plants by the production of phytohormones (Bashan \& Holguin, 1997) and are also possible suppliers of nitrogen to their host plants (Döbereiner, 1983; Okon, 1985). In addition, it has been reported that they possess oiloxidizing potential (Muratova et al., 2005). Currently, the genus comprises 11 species, namely Azospirillum lipoferum, A. brasilense, A. amazonense, A. halopraeferens, A. irakense, A. largimobile, A. doebereinerae, A. oryzae, A. melinis, A. canadense and $A$. zeae. In this paper, the taxonomic characterization of a strain (designated IMMIB AFH- ${ }^{\mathrm{T}}$ ) preliminarily identified as a member of the genus Azospirillum is reported.

Strain IMMIB AFH-6 ${ }^{\mathrm{T}}$ was isolated on nutrient agar from oil-contaminated soil near the oil refinery located in Kaohsiung county, Taiwan. The isolate was subsequently cultivated on brain-heart infusion (BHI) agar (no. 37100; Becton Dickinson) and tryptone soy agar (CM 131; Oxoid) to determine its morphological characteristics. 
The physiological properties of strain IMMIB AFH- $6^{\mathrm{T}}$ were determined by using the API CORYNE, API 20 STREP, API 20E and API 50CHE systems (bioMérieux). Assimilation tests were performed using the API 20NE system. Enzyme reactions and acid production from carbohydrates were determined after 3 and 7 days incubation at $37^{\circ} \mathrm{C}$. Salt tolerance was determined by cultivating the organism in tryptone soy broth supplemented with $\mathrm{NaCl}$ at final concentrations in the range 0.0 $12.0 \%(\mathrm{w} / \mathrm{v})$.

Chemotaxonomic characteristics of strain IMMIB AFH- $6^{\mathrm{T}}$ were determined by cultivating the organism at $37^{\circ} \mathrm{C}$ in shake flasks containing BHI broth for 1 week. After checking for purity at maximum growth, the organism was killed with formaldehyde $(1 \%, \mathrm{v} / \mathrm{v})$, harvested by centrifugation, washed with distilled water and freezedried. Lipids were extracted by using acid methanolysis as described by Minnikin et al. (1980). Fatty acids were analysed as described previously (Yassin et al., 2007). Respiratory quinones were extracted and purified according to Collins et al. (1977). MS analyses of the quinones were recorded in positive-ion mode on a Q-TOF 2 mass spectrometer (Micromass) equipped with a nanospray source as described previously (Yassin \& Hupfer, 2006). For the compounds under study, the major ions observed with electrospray were protonated pseudo-molecular ions, $[\mathrm{M}+\mathrm{Na}]^{+}$. The ubiquinone identity was verified by observing the diagnostic ion at $m / z=197$, which represents the benzylium ion.

Genomic DNA extraction, PCR-mediated amplification of the 16S rRNA gene and purification of PCR products were carried out by using procedures described by Rainey et al. (1996). Purified PCR products were sequenced by using a Taq DyeDeoxy Terminator Cycle Sequencing kit (Applied Biosystems) as described in the manufacturer's protocol. An Applied Biosystems 310 DNA Genetic Analyzer was used for electrophoresis of the sequence-reaction products.
The 16S rRNA gene sequences of species of Azospirillum with validly published names retrieved from GenBank were added to the ARB database (Ludwig et al., 2004) and aligned by using the respective tool of the ARB package. The resulting alignment was corrected manually and evolutionary trees were inferred by using maximum-parsimony (Fitch, 1971), neighbour-joining (Saitou \& Nei, 1987) and maximum-likelihood (Felsenstein, 1981) methods. An evolutionary-distance matrix was calculated by using the correction of Jukes \& Cantor (1969). Topologies of the resultant tree were evaluated in bootstrap analyses (Felsenstein, 1985) of the neighbour-joining method based on 1000 resamplings. DNA-DNA hybridization experiments were performed by using the method described by Ezaki et al. (1989) in triplicate $(n=3)$.

To establish the phylogenetic position of strain IMMIB AFH $-6^{\mathrm{T}}$, its $16 \mathrm{~S}$ rRNA gene sequence was determined in this study and subjected to comparative analysis. Treeing analysis demonstrated placement of the unidentified bacterium within the genus Azospirillum. Highest sequence similarities were shown to the type strains of $A$. canadense $(97.3 \%), A$. brasilense $(97.0 \%)$ and A. doebereinerae $(97.0 \%)$. Significantly lower similarity levels were shown to other members of the genus Azospirillum (data not shown). A tree constructed by using the maximumlikelihood method depicting the phylogenetic position of isolate IMMIB AFH- $6^{\mathrm{T}}$ within the genus Azospirillum is shown in Fig. 1 and demonstrates that the isolate represents a novel subline within the genus Azospirillum, with $A$. canadense as its closest phylogenetic relative. Branching of isolate IMMIB AFH $-6^{\mathrm{T}}$ with $A$. canadense was significant $(98 \%$ recovery in bootstrap resampling analysis). In view of the high $16 \mathrm{~S}$ rRNA gene sequence similarities between isolate IMMIB AFH- $6^{\mathrm{T}}$ and $A$. canadense, A. brasilense and A. doebereinerae, chromosomal DNA-DNA hybridizations were performed with these organisms. Reassociation values for isolate IMMIB

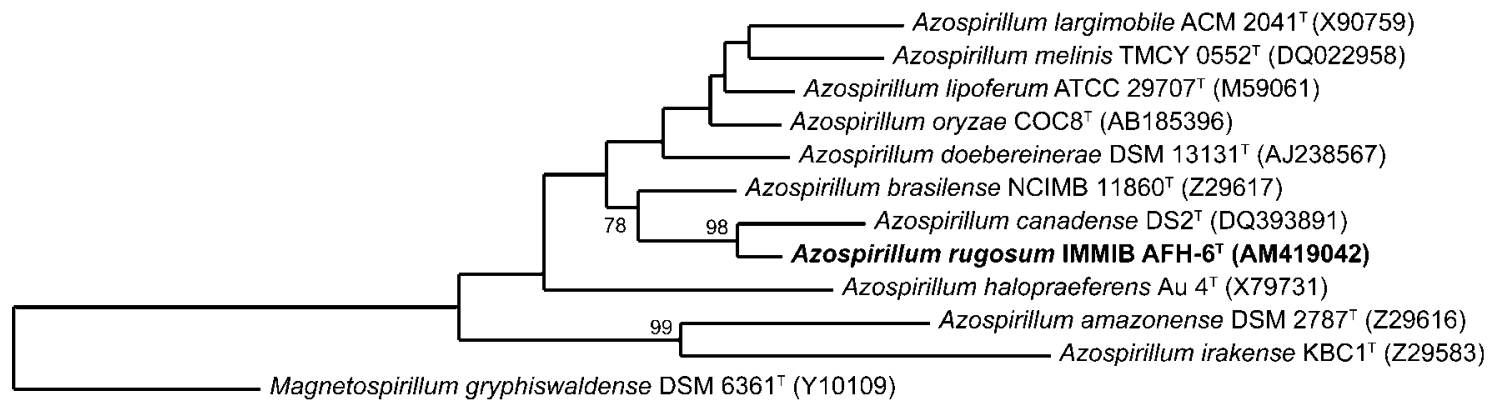

$5.0 \%$

Fig. 1. Maximum-likelihood tree showing the position of Azospirillum rugosum IMMIB AFH- ${ }^{\top}$ with respect to other members of the genus Azospirillum. The tree was based on a comparison of $16 \mathrm{~S}$ rRNA gene sequences that were at least $90 \%$ complete (with regard to the Escherichia coli sequence). Numbers at nodes are levels of bootstrap support (\%) based on analyses of 1000 resampled datasets. Bar, $5.0 \%$ sequence divergence. 
AFH $-6^{\mathrm{T}}$ with respect to $A$. canadense LMG $23617^{\mathrm{T}}, A$. brasilense DSM $1690^{\mathrm{T}}$ and A. doebereinerae DSM $13131^{\mathrm{T}}$ were $17.0,25.0$ and $19.0 \%$, respectively. These results demonstrate that isolate IMMIB AFH- $6^{\mathrm{T}}$ represents a separate species.

Chemotaxonomically, strain IMMIB AFH-6 ${ }^{\mathrm{T}}$ possesses chemical markers that support its assignment to the genus Azospirillum. Cellular fatty acid analysis revealed the presence of $n-C_{14: 0}\left(1.48 \%\right.$ of total fatty acids), $n-C_{15: 0}$ $(1.96 \%), n-C_{16: 1} \omega 7 c(18.02 \%), n-C_{16: 0}(12.40 \%)$, two isomers of 9,10-methylene-hexadecanoate $(0.55 \%$ and $1.28 \%), \quad \mathrm{n}-\mathrm{C}_{17: 0} \quad(0.43 \%), \quad \mathrm{n}-\mathrm{C}_{18: 2} \omega 6,9 c \quad(2.0 \%), \mathrm{n}-$ $\mathrm{C}_{18: 1} \omega 7 c(39.61 \%), \mathrm{n}-\mathrm{C}_{18: 0}(1.77 \%)$ and $\mathrm{n}-\mathrm{C}_{19: 1} \omega 9 c$ $(0.54 \%)$ as the major non-hydroxylated fatty acid methyl esters. Major hydroxylated fatty acids are $\mathrm{n}-\mathrm{C}_{14: 0} 3-\mathrm{OH}$ (5.6\%), n- $\mathrm{C}_{16: 0} 3-\mathrm{OH}(3.2 \%)$ and $\mathrm{n}-\mathrm{C}_{18: 0} 3-\mathrm{OH}(0.89 \%)$. The cellular fatty acid profile of strain IMMIB AFH- $6^{\mathrm{T}}$ and those of some Azospirillum species are shown in Table 1. According to GC-MS measurements, summed features 1, 2, 3 and 6 determined in this study (using the MIDI system)

Table 1. Comparison of the cellular fatty acid contents of strain IMMIB AFH-6 ${ }^{\top}$ and some Azospirillum species

Strains: 1 , strain IMMIB AFH-6 ${ }^{\mathrm{T}} ; 2$, A. canadense LMG $23617^{\mathrm{T}} ; 3$, A. brasilense DSM $1690^{\mathrm{T}} ; 4$, A. doebereinerae DSM $13131^{\mathrm{T}} ; 5$, A. oryzae $\mathrm{COC}^{\mathrm{T}}$ (Xie \& Yokota, 2005); 6, A. lipoferum ATCC $29707^{\mathrm{T}}$ (Mehnaz et al., 2007). Data are from this study except where indicated. -, Not detected.

\begin{tabular}{|lcccccc|}
\hline Fatty acid & $\mathbf{1}$ & $\mathbf{2}$ & $\mathbf{3}$ & $\mathbf{4}$ & $\mathbf{5}$ & $\mathbf{6}$ \\
\hline $\mathrm{n}-\mathrm{C}_{13: 0}$ & - & - & - & - & - & 0.5 \\
$\mathrm{n}-\mathrm{C}_{14: 0}$ & 1.48 & 0.02 & 0.04 & 0.06 & 0.9 & 0.7 \\
$\mathrm{n}-\mathrm{C}_{15: 0}$ & 1.96 & 0.30 & 0.30 & - & - & 1.4 \\
$\mathrm{n}-\mathrm{C}_{16: 1} \omega 9 c$ & 0.97 & 0.09 & 0.29 & 0.11 & - & - \\
$\mathrm{n}-\mathrm{C}_{16: 1} \omega 7 c$ & 18.02 & 6.13 & 7.96 & 7.09 & 16.1 & 6.5 \\
$\mathrm{n}-\mathrm{C}_{16: 1} \omega 5 c$ & 1.0 & 0.51 & 0.35 & 0.22 & - & - \\
$\mathrm{n}-\mathrm{C}_{16: 0}$ & 12.40 & 7.28 & 3.39 & 6.91 & 6.2 & 4.3 \\
$\mathrm{n}-\mathrm{C}_{17: 1} \omega 8 c$ & - & - & - & - & - & 3.4 \\
$9,10-\mathrm{Methylene}$ & 0.55 & 0.82 & 0.48 & 0.13 & - & - \\
hexadecanoate* & & & & & & \\
$9,10-\mathrm{Methylene}$ & 1.28 & 1.63 & 0.72 & 0.29 & - & - \\
$\mathrm{h}$ exadecanoate & & & & & & \\
$\mathrm{n}-\mathrm{C}_{17: 0}$ & 0.43 & 0.25 & 0.10 & - & - & 0.8 \\
$\mathrm{n}-\mathrm{C}_{18: 2} \omega 6,9 c$ & 2.0 & - & - & - & - & - \\
$\mathrm{n}-\mathrm{C}_{18: 1} \omega 7 c$ & 39.61 & 81.51 & 86.3 & 84.50 & 55.3 & 53.4 \\
$\mathrm{n}-\mathrm{C}_{18: 0}$ & 1.77 & 0.49 & 0.17 & 0.28 & - & 0.5 \\
$\mathrm{n}-\mathrm{C}_{19: 1} \omega 9 c$ & 0.54 & 1.07 & 0.04 & - & - & - \\
$\mathrm{n}-\mathrm{C}_{19: 0} \mathrm{cyclo} \omega 8 c$ & - & - & - & - & 3.8 & - \\
$\mathrm{n}-\mathrm{C}_{14: 0} 3-\mathrm{OH}$ & 5.6 & 18.43 & 14.18 & 52.67 & 6.7 & - \\
$\mathrm{n}-\mathrm{C}_{15: 0} 3-\mathrm{OH}$ & - & - & - & - & - & 0.8 \\
$\mathrm{n}-\mathrm{C}_{16: 0} 3-\mathrm{OH}$ & 3.2 & 55.42 & 38.14 & 45.07 & 4.8 & 4.3 \\
$\mathrm{n}-\mathrm{C}_{17: 0} 3-\mathrm{OH}$ & - & - & - & - & - & 0.6 \\
$\mathrm{n}-\mathrm{C}_{18: 0} 3-\mathrm{OH}$ & 0.89 & 1.28 & 1.12 & 2.26 & - & 0.5 \\
$\mathrm{n}-\mathrm{C}_{18: 0} 2-\mathrm{OH}$ & - & - & - & - & - & 5.5 \\
\hline
\end{tabular}

${ }^{\star}$ Two isomers of 9,10-methylene hexadecanoate. and in the studies of Mehnaz et al. (2007) and Xie \& Yokota (2005) should correspond to $n-C_{13: 0}, n-C_{14: 0} 3$ $\mathrm{OH}, \mathrm{n}-\mathrm{C}_{16: 1} \omega 7 c$ and $\mathrm{n}-\mathrm{C}_{18: 2} \omega 6,9 c$, respectively. MS analysis of the main isoprenoid quinone isolated from strain IMMIB AFH- $6^{\mathrm{T}}$ showed a strong peak at $\mathrm{m} / \mathrm{z}$ $=885.57$, attributable to $[\mathrm{M}+\mathrm{Na}]^{+}$in the high-mass region. This corresponds to a ubiquinone with ten isoprene units (Q-10).

Strain IMMIB AFH- $6^{\mathrm{T}}$ consisted of Gram-negative, straight to slightly curved rods. On BHI agar, nutrient agar and tryptone soy agar, young colonies were smooth with entire margins, but older colonies become wrinkled with an irregular appearance. Colonies were light-orangecoloured. The organism grew aerobically and was catalaseand oxidase-positive. It hydrolysed gelatin, hippurate and aesculin. It reduced nitrate to nitrite. It had arginine dihydrolase, para-nitrophenyl- $\beta$-D-galactopyranosidase, ortho-nitrophenyl- $\beta$-D-galactopyranosidase and urease activities. Comparative biochemical studies (Table 2) revealed that isolate IMMIB AFH- $6^{\mathrm{T}}$ could be differentiated from its close phylogenetic relatives (A. canadense, $A$. brasilense and $A$. doebereinerae) on the basis of carbonsource utilization, gelatin hydrolysis, nitrate reduction and arginine dihydrolase activity.

It is evident from the presented data that isolate IMMIB AFH- $6^{\mathrm{T}}$ exhibits overall cellular morphological and chemotaxonomic characteristics that are consistent with those of members of the genus Azospirillum, but appears not to conform to any recognized species. Phylogenetic analysis based on 16S rRNA gene sequencing confirmed this provisional assignment and demonstrated clearly that isolate IMMIB AFH $-6^{\mathrm{T}}$ represents an unknown subline within the genus Azospirillum. Both sequence-divergence values and branching-pattern considerations show that the unidentified organism is related more closely to $A$.

Table 2. Characteristics that differentiate strain IMMIB AFH- $6^{\top}$ from the most phylogenetically related Azospirillum species

Taxa: 1, strain IMMIB AFH-6 ${ }^{\mathrm{T}}$; 2, A. canadense LMG $23617^{\mathrm{T}}$; 3 , A. brasilense DSM $1690^{\mathrm{T}} ; 4$, A. doebereinerae DSM $13131^{\mathrm{T}}$. All strains are positive for assimilation of D-fructose, D-gluconate, glycerol and malic acid, but are negative for assimilation of $\mathrm{N}$-acetylglucosamine, cellobiose, D-glucose, inositol, maltose, D-mannitol, D-mannose and D-sorbitol. All data are from this study and were determined by using API 20NE tests.

\begin{tabular}{|lcccc|}
\hline Characteristic & $\mathbf{1}$ & $\mathbf{2}$ & $\mathbf{3}$ & $\mathbf{4}$ \\
\hline Assimilation of: & & & & \\
L-Arabinose & - & + & + & + \\
D-Galactose & - & - & + & + \\
Adipic acid & + & - & - & - \\
Gelatin hydrolysis & + & - & + & + \\
Reduction of nitrate & + & + & - & - \\
Arginine dihydrolase & - & - & + & + \\
\hline
\end{tabular}


canadense than to $A$. brasilense and A. doebereinerae. However, chromosomal DNA-DNA pairing demonstrates that these organisms represent separate species. Support for the separateness of isolate IMMIB AFH $-6^{\mathrm{T}}$ also comes from its distinct biochemical characteristics. Therefore, based on biochemical and molecular genetic evidence, it is proposed that isolate IMMIB AFH- $6^{\text {T }}$ should be classified in the genus Azospirillum as Azospirillum rugosum sp. nov.

\section{Description of Azospirillum rugosum sp. nov.}

Azospirillum rugosum (ru.go'sum. L. neut. adj. rugosum wrinkled, as the form of the colonies on the agar changes to a wrinkled appearance).

Cells are straight to slightly curved rods and motile. Gramnegative, oxidase- and catalase-positive. Ageing cells contain intracellular granules. On tryptone soy agar, nutrient agar and BHI agar, light-orange colonies are formed that are initially smooth with entire margins, becoming wrinkled and irregular with age. Aerobic. Grows at $22-37{ }^{\circ} \mathrm{C}$ and tolerates $2.0 \%(\mathrm{w} / \mathrm{v}) \mathrm{NaCl}$. Has the salient chemotaxonomic characteristics of the genus Azospirillum. The fatty acid profile consists mainly of straight-chain saturated and unsaturated fatty acids, with $\mathrm{n}-\mathrm{C}_{18: 1} \omega 7 c$ as the major fatty acid, as well as $3-\mathrm{OH}$ hydroxylated fatty acids. The respiratory quinone consists of ubiquinone with ten isoprene units (Q-10). Gelatin, hippurate and aesculin are hydrolysed. Adipic acid, D-fructose, glycerol, potassium gluconate, 2-ketogluconate, malic acid and D-xylose are assimilated, but arbutin, D-glucose, D- and L-arabinose, Dand L-mannose, D-mannitol, $N$-acetylglucosamine, maltose, capric acid, phenylacetic acid and trisodium citrate are not. Acid is produced from D-fructose and D-xylose, but not from $\mathrm{N}$-acetylglucosamine, D-adonitol, starch, amygdalin, D- and L-arabinose, D- and L-arabitol, arbutin, cellobiose, citrate, dulcitol, inositol, gentiobiose, glycerol, glycogen, gluconate, D-galactose, D-glucose, D- and L-fucose, inositol, inulin, D-lactose, maltose, D-mannitol, D-mannose, melibiose, melezitose, D-lactose, D-lyxose, raffinose, L-rhamnose, D-ribose, salicin, D-sorbitol, L-sorbose, sucrose, D-tagatose, trehalose, turanose, xylitol or L-xylose. Positive for nitrate reductase, alkaline phosphatase, arginine dihydrolase, $\alpha$ galactosidase, 2 -nitrophenyl- $\beta$-D-galactopyranosidase, 4 nitrophenyl- $\beta$-D-galactopyranosidase, lysine decarboxylase, ornithine decarboxylase, pyrazinamidase and urease activities, but negative for $\alpha$-glucosidase, $\beta$-galactosidase, $\beta$ glucuronidase, $N$-acetyl- $\beta$-glucosaminidase, leucine aminopeptidase, tryptophan deaminase and pyrrolidonyl arylamidase activities. Positive for acetoin production (VogesProskauer), but negative for indole and $\mathrm{H}_{2} \mathrm{~S}$ production.

The type strain is IMMIB AFH $-6^{\mathrm{T}}\left(=\right.$ CCUG $53966^{\mathrm{T}}=\mathrm{DSM}$ $\left.19657^{\mathrm{T}}\right)$, isolated from oil-contaminated soil.

\section{Acknowledgements}

We thank Professor Dr Hans-Georg Trüper for nomenclatural advice. This research work was kindly supported by a grant from the National
Science Council and the Council of Agriculture, Executive Yuan, Taiwan, Republic of China.

\section{References}

Bally, R., Thomas-Bauzon, D., Heulin, T., Balandreau, J., Richard, C. \& De Ley, J. (1983). Determination of the most frequent $\mathrm{N}_{2}$-fixing bacteria in a rice rhizosphere. Can J Microbiol 29, 881-887.

Bashan, Y. \& Holguin, G. (1997). Azospirillum-plant relationships: environmental and physiological advances (1990-1996). Can J Microbiol 43, 103-121.

Collins, M. D., Pirouz, T., Goodfellow, M. \& Minnikin, D. E. (1977). Distribution of menaquinones in actinomycetes and corynebacteria. J Gen Microbiol 100, 221-230.

Döbereiner, J. (1983). Ten years of Azospirillum. In Azospirillum II: Genetics, Physiology, Ecology, pp. 9-23. Edited by W. Klingmüller. Basel: Birkhäuser.

Döbereiner, J., Marriel, I. E. \& Nery, M. (1976). Ecological distribution of Spirillum lipoferum Beijerinck. Can J Microbiol 22, 1464-1474.

Ezaki, T., Hashimoto, Y. \& Yabuuchi, E. (1989). Fluorometric deoxyribonucleic acid-deoxyribonucleic acid hybridization in microdilution wells as an alternative to membrane filter hybridization in which radioisotopes are used to determine genetic relatedness among bacterial strains. Int J Syst Bacteriol 39, 224-229.

Felsenstein, J. (1981). Evolutionary trees from DNA sequences: a maximum likelihood approach. J Mol Evol 17, 368-376.

Felsenstein, J. (1985). Confidence limits on phylogenies: an approach using the bootstrap. Evolution 39, 783-791.

Fitch, W. M. (1971). Toward defining the course of evolution: minimum change for a specific tree topology. Syst Zool 20, 406-416.

Gunarto, L., Adachi, K. \& Senboku, T. (1999). Isolation and selection of indigenous Azospirillum spp. from a subtropical island, and effect of inoculation on growth of lowland rice under several levels of $\mathrm{N}$ application. Biol Fertil Soils 28, 129-135.

Jukes, T. H. \& Cantor, C. R. (1969). Evolution of protein molecules. In Mammalian Protein Metabolism, vol. 3, pp. 21-132. Edited by H. N. Munro. New York: Academic Press.

Kirchhof, G., Reis, V. M., Baldani, J. I., Eckert, B., Doebereiner, J. \& Hartmann, A. (1997). Occurrence, physiological and molecular analysis of endophytic diazotrophic bacteria in gramineous energy plants. Plant Soil 194, 45-55.

Ladha, J. K., So, R. B. \& Watanabe, I. (1987). Composition of Azospirillum species associated with wetland rice plants grown in different soils. Plant Soil 102, 127-129.

Ludwig, W., Strunk, O., Westram, R., Richter, L., Meier, H., Yadhukumar, Buchner, A., Lai, T., Steppi, S. \& other authors (2004). ARB: a software environment for sequence data. Nucleic Acids Res 32, 1363-1371.

Mehnaz, S., Weselwski, B. \& Lazarovits, G. (2007). Azospirillum canadense sp. nov., a nitrogen-fixing bacterium isolated from corn rhizosphere. Int J Syst Evol Microbiol 57, 620-624.

Minnikin, D. E., Hutchinson, I. G., Caldicott, A. B. \& Goodfellow, M. (1980). Thin-layer chromatography of methanolysates of mycolic acid-containing bacteria. J Chromatogr 188, 221-223.

Muratova, A. lu., Turkovskaia, O. V., Antoniuk, L. P., Makarov, O. E., Pozdniakova, L. I. \& Ignatov, V. V. (2005). Oil-oxidizing potential of associative rhizobacteria of the genus Azospirillum. Microbiology (English translation of Mikrobiologiia) 74, 248-254.

Okon, Y. (1985). Azospirillum as a potential inoculant for agriculture. Trends Biotechnol 3, 223-228. 
Rainey, F. A., Ward-Rainey, N., Kroppenstedt, R. M. \& Stackebrandt, E. (1996). The genus Nocardiopsis represents a phylogenetically coherent taxon and a distinct actinomycete lineage: proposal of Nocardiopsiaceae fam. nov. Int J Syst Bacteriol 46, $1088-1092$.

Saitou, N. \& Nei, M. (1987). The neighbor-joining method: a new method for reconstructing phylogenetic trees. Mol Biol Evol 4, 406-425.

Tarrand, J. J., Krieg, N. R. \& Dobereiner, J. (1978). A taxonomic study of the Spirillum lipoferum group, with descriptions of a new genus, Azospirillum gen. nov., and two species, Azospirillum lipoferum
(Beijerinck) comb. nov. and Azospirillum brasilense sp. nov. Can J Microbiol 24, 967-980.

Xie, C.-H. \& Yokota, A. (2005). Azospirillum oryzae sp. nov., a nitrogen-fixing bacterium isolated from the roots of the rice plant Oryza sativa. Int J Syst Evol Microbiol 55, 1435-1438.

Yassin, A. F. \& Hupfer, H. (2006). Williamsia deligens sp. nov., isolated from human blood. Int J Syst Evol Microbiol 56, 193-197.

Yassin, A. F., Chen, W.-M., Hupfer, H., Siering, C., Kroppenstedt, R. M., Arun, A. B., Lai, W.-A., Shen, F.-T., Rekha, P. D. \& Young, C. C. (2007). Lysobacter defluvii sp. nov., isolated from municipal solid waste. Int J Syst Evol Microbiol 57, 1131-1136. 